\title{
Eutrofização em estuários: uso de íons fosfato e sílica em águas intersticiais estuarinas da Baixada Santista (SP) como marcadores de ambientes impactados
}

\author{
Wanilson Luiz Silva (PQ), Thaís de Paula Marteleto (IC).
}

\begin{abstract}
Dissolved nutrients in sediment interstitial water of highly polluted estuaries in São Paulo State, southeastern Brazil, were analyzed by ultraviolet-visible spectrophotometry in order to assess the health of ecosystems. High mean contents of phosphate $\left(12.8 \mathrm{mg} \mathrm{L}^{-1}\right)$ and silica $\left(11.4 \mathrm{mg} \mathrm{L}^{-1}\right)$ were found, which seem to be influenced by effluents from urban and industrial sources. As a result, the sediments can play a significant role in the process of eutrophication of estuaries especially considering phosphorus release from the sediment pore water to the overlying water.
\end{abstract}

Palavras Chave: Nutrientes, eutrofização, espectrofotometria UV-vis.

\section{Introdução}

Este estudo avaliou as concentrações de nutrientes em águas intersticiais de sedimentos de estuários da Baixada Santista (SP), que abrigam o Polo Industrial de Cubatão (o maior da América Latina) e cidades densamente povoadas (mais de um milhão de habitantes). O objetivo do trabalho foi avaliar os níveis de nutrientes dissolvidos nas águas intersticiais e sua relação com fontes industriais e urbanas, que podem impulsionar processos de eutrofização e colocar em risco o equilíbrio dos ecossistemas. Amostras de sedimentos de superfície foram coletadas em três estações na borda entre os manguezais e os canais fluviais dos rios Morrão, Cubatão e Branco, e a água contida nos poros dos sedimentos foi extraída por centrifugação e filtrada em membrana celulósica $(0,22 \mu \mathrm{m}$ de poros). Os nutrientes nestas águas foram analisados por espectrofotometria UV-vis (880 $\mathrm{nm}$ para fosfato $810 \mathrm{~nm}$ para sílica), após diluição da amostra em até 6 vezes.

\section{Resultados e Discussão}

As concentrações de fosfato e sílica dissolvidas foram elevadas e, na média geral, semelhantes entre si, mas variaram significativamente entre os estuários estudados (Tabela 1). Em geral, o fosfato foi superior nas águas intersticiais do rio Branco, cujo ponto de coleta foi situado entre núcleos urbanos e o Porto de Santos, o maior da América Latina. Este íon também mostrou conteúdo expressivo no rio Morrão, o ponto de coleta mais próximo a indústrias de fertilizantes e situado à montante de núcleos urbanos. Já a estação do rio Cubatão apresentou as menores médias de fosfato, possivelmente devido a sua maior distância de fontes antrópicas (industriais e urbanas).
Tabela 1. Intervalos e médias de concentrações (mg $\left.\mathrm{L}^{-1}\right)$ de fosfato e sílica em águas intersticiais estuarinas da área de estudo.

\begin{tabular}{lcccl}
\hline & \multicolumn{2}{c}{ Fosfato } & \multicolumn{2}{c}{ Sílica } \\
\hline Rio Morrão & $2,1-21,4$ & $12,2 \pm 7,4$ & $5,4-29,9$ & $16,2 \pm 5,6$ \\
Rio Cubatão & $0,3-18,8$ & $7,4 \pm 5,8$ & $0,4-15,1$ & $7,4 \pm 3,9$ \\
Rio Branco & $15,2-24,3$ & $18,8 \pm 2,4$ & $6,6-17,0$ & $10,5 \pm 2,5$ \\
Média geral & & $12,2 \pm 7,2$ & & $11,2 \pm 5,6$ \\
\hline
\end{tabular}

Os níveis de sílica foram mais elevados nas águas intersticiais nas proximidades de indústrias (rio Morrão), que podem contribuir com este nutriente para 0 ambiente, além do fluxo natural do intemperismo. As concentrações de fosfato e sílica máximas em águas intersticiais mostradas neste estudo são superiores às reportadas para águas de superfície da mesma área, ${ }^{1}$ e o aporte antrópico de nutrientes parece exercer um papel importante neste enriquecimento.

\section{Conclusões}

As águas intersticiais estudadas são afetadas por introdução antrópica elevada de fosfato e sílica. Como resultado, o compartimento sedimentar pode funcionar como um reservatório de nutrientes com potencial para eutrofização.

\footnotetext{
Braga, E.S.; Bonetti, C.V.D.H.; Burone, L.; Bonetti-Filho, J. Eutrophication and bacterial pollution caused by industrial and domestic wastes at the Baixada Santista Estuarine System - Brazil. Marine Pollution Bolletin. 2000, 40, 165-173.
} 